Research, part of a Special Feature on Global Water Governance: Challenges and Future Scope

\title{
Ethics and Water Governance
}

\author{
David Groenfeldt ${ }^{1,2}$ and Jeremy J. Schmidt ${ }^{3}$
}

ABSTRACT. Ethics and values are important dimensions of water governance. We show how a "values approach" contributes to an understanding of global water governance, and how it complements other perspectives on governance, namely management, institutional capacity, and social-ecological systems. We connect these other approaches to their own value systems and the ethical attitudes they engender. We then offer a way to explicitly incorporate, and where necessary adjudicate, competing value systems through a values-based approach to governance. A case of the Santa Fe River in New Mexico, USA illustrates how value systems are reflected in water policies and how these values affect governance priorities, such as in environmental flows. The values-based approach clarifies tacit values and creates space to align local values with those needed for effective water governance at the global level.

Key Words: ethics; Rio Grande; Santa Fe, New Mexico; Santa Fe River; values; water governance

\section{INTRODUCTION}

From the local to the global level, values are central to ordering water for the purposes of governance. Values are personal or cultural standards that give intrinsic or extrinsic worth to subjects, objects, or behavior, and which delimit the sphere of moral consideration. Without values, governance has no referent for adjudicating competing demands or for assessing different institutional paths. While governance systems typically deal with the behavioral expression of values (e.g., building a dam) or with defining governance aims (e.g., achieving efficiency), the values that legitimate behaviors and institutional cultures often go unattended. Yet contemporary governance models are often characterized as inadequate because they do not accord with new or changing values. For instance, "command-and-control" governance is criticized for being prescriptive, fragmented, and adversarial and for failing to reflect values of participation and social learning (Durant et al. 2004). Similarly, market-based governance is criticized for not taking ecological perspectives into account. When values are not explicitly considered, governance norms lack orientation (cf. Pahl-Wostl et al. 2008).

This paper considers the role of values in water governance, as defined in Gupta et al. (2013). Huitema et al. (2009) demonstrated that governance is polycentric, with multiple institutions holding power in overlapping ways that affect decision making in complex ways. In decentralized water governance, success depends on initial social and ecological conditions, the biophysical scale at which problems are framed, and the types of governance changes sought (cf. Dinar et al. 2007). Achieving gender equity, for instance, requires deliberation at multiple scales and in view of the different religious, cultural, and legal spheres affecting the (often differential) water rights of men and women (Zwarteveen and Meinzin-Dick 2001). Operative values linking social and ecological systems to governance norms are not particular to any one scale.
We begin by considering a values-based approach in reference to other water governance perspectives. Using a case study from New Mexico, USA, the paper then illustrates how values serve as drivers of water governance. The case study supports a two-part thesis: (1) that values pervade all approaches to water governance, and (2) that explicitly attending to values through the cultivation of a water ethic enables global water governance to link issues that arise across place and scale. This is because a focus on water ethics requires explicit engagement with values and support of the values that affect governance through public reasoning.

\section{FOUR OVERLAPPING APPROACHES}

Before presenting the "values approach" to water governance, it is helpful to review other perspectives that contextualize efforts toward global water governance. We consider three: (1) a management perspective, designed to unite both physical and social concerns; (2) an institutional perspective, of applied economics, political science, and law; and (3) a sustainability perspective, focused on social-ecological dimensions of water systems. After surveying each, we introduce a fourth: the values-based approach.

\section{Management}

Although historical antecedents reach back further (Cech 2004), for much of the twentieth century, water management was essentially about control, with engineering works gradually expanding from single purposes and single means to multiple purposes through multiple means (White 1969). The focus was on supply-side development, with management following to improve efficiency amongst competing social and environmental demands (Pigram 2006). In 1984, the International Water Management Institute (IWMI) was established, which symbolized a shift away from strictly engineering perspectives. IWMI's approach was to apply management science borrowed from business and organizational models to realize the productive potential of 
high-cost irrigation investments (see Coward 1980, Wickham 1985, Korten and Siy 1988). IWMI's establishment occurred amidst broader trends in water resources management, and the idea that rational planning could integrate whole river basins for optimal efficiency at national, regional, and sectoral scales (Biswas 1978, Molle 2009). This model attempts to synthesize data from scientific, technological, and socioeconomic systems in a manner that organizes water management concerns objectively (Wiener 1972).

Despite the claim to objectivity, rational planning harbors two normative criteria (Lindblom 1999). First, managers not only formulate possible courses of action, they also evaluate them. Second, choices between possible courses of action suppress alternatives considered rational by some parties. Likewise, the quest for "good governance" requires coordinating multiple normative viewpoints. In irrigation, for instance, water productivity is a standard utilitarian objective but equity is also important (Pant 1984, Brown and Ingram 1987, Chambers et al. 1989). Similarly, governance objectives often include the empowerment of rural women (Merrey and Baviskar 1998), enhancing the livelihoods of indigenous peoples (Phansalkar and Verma 2004), and participatory development of rural communities (Groenfeldt 1988). Selecting particular criteria has the effect of standardizing indicators to assess performance (cf. Malano and Burton 2001).

\section{Institutions}

The shortcomings of management approaches to governance encouraged institutional perspectives that, inter alia, aimed at enhancing the role of the private sector in water governance. Some notable failures (see Bauer 2004) revealed the deeply political nature of governance and the many variables that affect how water is coordinated across scales (cf. Ostrom 1990). Thus, political, economic, and legal institutions already impinging on water, such as cooperative irrigation, are a key contextual factor for understanding operational norms (Ostrom 1992). Ensuring the effectiveness of governance transitions therefore requires an understanding of how actors navigate socio-cultural norms and how ecosystems are comprehended vis-à-vis different culturally grounded rights regimes (Agrawal 2003, Sandberg 2007).

Nuanced approaches to institutional considerations have drawn attention to the rich potential for integrating social and economic development (e.g., Dasgupta and Serageldin 2000). Robert Chambers (2007), and the Participatory Learning and Action network that he and his associates inspired, provided an ethical orientation to work on institutional and social capital. Critically, the focus on institutional dimensions in governance necessitated recognition that "command-andcontrol" attitudes are out of step with the larger socialecological systems in which institutions are embedded (Ostrom 2009) and the polycentric dynamics of multilevel governance (Ostrom 2010). To re-orient institutions, new approaches require understanding social-ecological systems as being characterized by change and as behaving in nonlinear ways (Gunderson and Holling 2002). The implications for governance are many. Law, for instance, has little or no precedent for conceptualizing problems or formulating legal tests in nonlinear terms (Tarlock 1993). And when rivers are used as legal boundaries, the complex processes that lead to nonlinear channel shifts can confuse the basic spatial categories that were designed to simplify institutional problems (Blomley 2008).

\section{Social-ecological systems}

The unique contribution of the social-ecological perspective is that it allows for an assessment of how water management decisions affect environmental outcomes, such as biodiversity loss (Brierley and Fryiers 2008), and socio-cultural outcomes, such as forced resettlement or in situ loss of livelihood (Johnston 1994). When social and environmental implications are considered we are reminded that there are numerous political and value factors embedded in naturalized concepts such as "watersheds" (Warner et al. 2008). Analogously, there are value judgments embedded in how we classify water visà-vis complex social-ecological systems. For example, environmental flow refers to how much water is needed by a river and when, in order to support the river's basic ecological functions. Negotiating social and ecological water uses requires revisiting the fit of empirical standards with changing systems (Dyson et al. 2003, Arthington et al. 2006, King and Brown 2006) and acknowledging that we have little or no data for scientifically establishing environmental flows on many watercourses (Acreman et al. 2008). The development of environmental flow standards requires new norms for governing complex systems and for stewarding both "offstream" uses of water, such as those benefiting society, and "instream" flow needs of riparian ecosystems (Annear et al. 2002, Postel and Richter 2003). Likewise, classifying blue vs. green water distinguishes between visible (blue) watersuch as rivers, rainfall, and aquifers-and the invisible (green) water content of soil and evapotranspiration from plants. Generally speaking, the task of water management has focused on blue water only, whereas the many human-induced impacts on green water (e.g., through urban expansion and agriculture) have been largely ignored (Falkenmark and Folke 2002, Falkenmark and Rockström 2004). Yet once we consider both blue and green water as part of coupled and complex socialecological systems, there are no neutral starting points from which to calculate which water to manage and which to leave alone (cf. Falkenmark and Folke 2010, Folke 2003).

\section{Values-based approach}

The contrast between Postel and Richter (2003) and Falkenmark and Folke (2010) highlights why a values-based approach is germane to water governance. The former hold that we need to see water as the kind of thing we should refrain from wholly subjecting to management. Postel (2008) has 
argued that we should even extend certain rights to water itself. By contrast, the latter view water as the kind of thing that we should manage fully for human well-being given the human effects across entire social-ecological systems. In both cases norms produce different classes of water (e.g., environmental flows, blue-green water flows) in ways that affect governance. These two cases illustrate the types of value judgments that become apparent once we analyze governance dynamics in view of the dominant effects of humans on coupled socialecological systems (see Lövbrand et al. 2009). Further, value dimensions multiply in transboundary governance and reveal how different cultures use competing categories to understand what kind of thing water is and to reason about facts in the context of particular meanings of water (Blatter and Ingram 2001). The very project of global governance creates new kinds of knowledge and new values (Hulme 2010). This is to say nothing of the other values that support western classifications of water, such as in "urban" or "waste" water (see Illich 1986, Gaard 2001). The upshot is a complex, often overburdened terrain regarding how values contextualize water governance.

\section{From values to ethics}

The term "ethics" can refer to two related but distinct concepts. One is value-based and objective; the important feature of this view of ethics is that it is descriptive in the sense that reasons to act one way rather than another are based on facts about the objects of our actions or desires. These "[o]bject-given reasons are provided by the facts that make certain outcomes worth producing or preventing, or make certain things worth doing for their own sake" (Parfit 2011:45). Another meaning of ethics is subject-given. This view suggests that reasons to act one way or another depend on facts about what we would do to fulfill our desires or preferences. Environmental philosophers, such as Rolston (2010), have derided subjectivist views for their lack of fit with scientific facts and for the suggestion that although humans emerge from a long evolution of life, they somehow bring all of the value into the world.

We consider ethics in the objective sense, and use this to understand how governance conflicts are rooted in values that order and legitimate conduct toward certain ends and not others. For instance, the task of building institutions for global water governance has been highly contentious, specifically regarding how to achieve integrated water resources management (IWRM) (Conca 2006). There has been a long history of efforts towards integrated water resources management using various governance models (see White 1998, Rahaman and Varis 2005) but since the 1992 "Dublin Principles" this project has been advanced by understanding water as a scarce resource with an economic value in all of its competing uses. This claim has been very divisive because how we respond to facts about water scarcity depends on how we reason about it (Soderbaum 2008) and on our understanding of economic value (Hanemann 2006). In view of polycentricity, it is evident that facts about water scarcity can be reasoned about not only economically, but also from the reference frames of indigenous communities (Boelens et al. 2006, Boelens et al. 2010) and religious traditions and practices (Chamberlain 2008, Shaw and Francis 2008), or through celebrations of creative solidarity (Gerber 2003, Irland 2007).

\section{APPLYING ETHICS TO WATER GOVERNANCE}

Nobody denies the value of water, yet explicit attention to ethics has largely been absent in discussions of water governance. Fortunately, that tide is going out. Here we do not summarize the philosophic discourse on water ethics (see Brown and Schmidt 2010) or the ethical considerations at play in the politics of governance (see Whiteley et al. 2008, Llamas et al. 2009). Rather, we consider how attending to ethics supports the task of finding governance arrangements that not only recognize multiple values, but it also provides a framework for reasoning about alternate options.

\section{Step 1: identify inherited values}

Identifying the operative values underlying particular behaviors is the first step in the process of harmonizing values with desirable governance outcomes. Merchant (1997) notes that from a resource management perspective, twentiethcentury ethics were primarily utilitarian and took the interests of society (rather than the individual self) as the impetus for normative legitimacy. This utilitarian view was articulated initially in the United States and has gradually extended internationally (Feldman 1995, 2007). This ability to "jump scales" is afforded by the utilitarian focus on consequences, so what is good in one case may not be in another, depending on what produces the greatest good. Another reason for its pervasive acceptance is that utilitarianism aligns well with governance institutions that claim objectivity based on hegemonic models of western rationality (see Blatter and Ingram 2001, Wolf 2008). For instance, individuals are often conceived of as being rational and self-interested and as navigating social and cultural norms so as to maximize benefits while respecting social structures (Ostrom 2005). Likewise, oft-cited definitions of integrated water resources management promote utilitarian governance where the goal is to "maximize . . . economic and social welfare" without compromising the environment (Agarwal et al. 2000:22).

\section{Step 2: reason about values}

The central ethical issue of utilitarian governance is whether the valuation of water should be linked only to the consequences of certain uses or whether there should also be a consideration of whether water is distributed equitablybecause how water is distributed also has ethical consequences. International water management regimes, for instance, are beset by a longstanding dialectic over whether the greatest good is produced through rational planning norms 
versus those of privatization (Delli Priscoli 1996). These conflicts within utilitarianism occupy much of the debate over how to achieve good governance. Yet the very idea of employing utilitarianism to coordinate governance tasks has been heavily scrutinized in water governance (Feldman 2007) and in environmental law (Freyfogle 1996, Kysar 2010). Critics of utilitarianism argue that it is concerned primarily with maximizing the production of water-related goods rather than with how the uniform creation of rights that are conducive to utilitarian governance affect other forms of governance which may already be operating (see Swyngedouw 2005).

The values approach also allows us to identify how values have been reasoned about to support specific ethical positions. For instance, in the western United States the doctrine of "prior appropriation" was initially designed to ensure just distributive practices by ensuring that water was diverted for legitimate uses and that capitalists would not accumulate water rights (Schorr 2005). However, the particular institutional design of prior appropriation rights (first-in-time, first-inright) is also conducive to utilitarian markets, which some economists say is the way to re-interpret these rights for valuing instream flows and increasing efficiency (i.e., Anderson and Leal 2001). However, appropriative rights were not designed to recognize benefits from leaving water in situ or to function as private property (Schorr 2005). Further, because the "markets" for water's ecological services do not have clear supply/demand scenarios, prices are often set politically (at best) or arbitrarily (at worst) (Robertson 2007). As such, re-interpreting prior appropriation in economic terms is also a conversation about which values are taken to underlie it, and about the reasoning that supports the use of those values over others.

\section{Step 3: order water anew}

At the global level, diverse water values are not easy to reconcile (Delli Priscoli et al. 2004) but they are critical for both water and food security (Garrido and Ingram 2011). Selborne's (2000) report suggests governance must consider competing values of efficiency, ecological design, intrinsic value, pricing, stakeholder consensus, and communitarianism (as a way beyond the public/private dichotomy). Further work by UNESCO has identified the range of governance issues that values must be scaled to fit, such as groundwater withdrawals (Llamas 2004), gender inequity (Aureli and Brelet 2004), institutional organization (Barraqu 2004), and ecosystem function (Acreman 2004).

The values approach suggests that making our water ethic explicit is one way to re-order the tasks of governance. Such an approach has been evolving in Canada's Northwest Territories (NWT), parts of which are downstream of the world's largest unconventional fossil fuel energy development project - the Alberta oil sands. Vaux (2010:531) argues for a joint solution of economic equity and resource policy through “. . . the enforcement of existing laws and treaties by the national government of Canada." This solution, however, offers only an economic view of equity, and does not capture the other objects of value that the Northwest Territories strategy considers in its definition of "sustainability accounting". This view considers multiple points of reference for reasoning about the value of water, and in light of how cultural values may be different in kind from economic ones (Northwest Territories 2010). As Sandford and Phare (2011) argue, the departure point of the Northwest Territories strategy offers a way to develop a water ethic that addresses facts about the differential effects of development across worldviews, especially on indigenous communities, and a way to reconcile the aims of governance with the fact that water has different instrumental and intrinsic meanings for indigenous and nonindigenous peoples in Canada.

Recognizing diverse sources of normative legitimacy is a prerequisite for understanding the polycentric dynamics of global water governance. Yet it leads to a second consideration, which is to respect the place-based ways in which different cultures order water under categories that may be incommensurable (Espelund 1998, Whiteley et al. 2008). Further, a values-based approach respects the important role of emotion that affects the political, lived experiences of those affected by governance decisions (see Sultana 2011). Because values do not emerge from nowhere, the values based approach offers the opportunity to connect issues of place and scale to the water ethic(s) used to pursue certain policy paths over others.

\section{CASE STUDY: THE SANTA FE RIVER IN NEW MEXICO}

The Santa Fe River in northern New Mexico, USA descends from the Sangre de Cristo Mountains which are east of Santa Fe City and flows $72 \mathrm{~km}$ west to the Rio Grande. Just before leaving the mountains, it is impounded in two reservoirs that provide about one-third of the City's water supply. Historically, the river and associated shallow wells comprised all of the City's water supply. The supply has since been supplemented by deep wells and by a diversion and pipeline from the Rio Grande, some $20 \mathrm{~km}$ distant.

The history of the Santa Fe basin reveals a succession of cultures and corresponding values about the river. Indigenous Pueblo Indian tribes were already using the Santa Fe River for irrigation when the Spanish arrived in the late 1500s. With the establishment of Santa $\mathrm{Fe}$ as a provincial capitol in 1610, agricultural use of water intensified and the Santa Fe River provided water to a growing network of Spanish canals (acequias). More than 30 acequias were established, irrigating roughly 800 ha of farmland and diverting enough water such that stretches of the river were dry during the summer months.

\section{Inherited values}

A core value of acequia agriculture is the sharing of water to support life. "The principle of water sharing belongs to a larger 
moral economy that promotes cooperative economic behavior through inculcating the core value of respect and gendered norms of personal comportment" (Rodriguez 2006:116). This tradition was dominant during the Spanish and Mexican eras, and exists today among the remaining acequias in northern New Mexico. New cultural values about water were ushered in with the American annexation of New Mexico in 1848. For instance, the doctrine of prior appropriation gave legal water rights to people who diverted water from the river for economic use. Omitted from these new laws was any consideration of the river itself. In 1881, a dam was built to provide municipal water for the newly established Santa Fe Water Company that sold piped water to residents. This event marks the introduction of a new kind of water ethic. For the first time, water had monetary worth, and governance passed from communal to private ownership. Initially, the Water Company stored less than $10 \%$ of the river's flow for its customers, but that proportion grew steadily with the construction of larger dams.

The modern river has been managed to maximize the water volume stored in the reservoirs and minimize water that is "spilled" into the otherwise dry river channel. The City's water rights to 5040 acre feet $\left(6,214,320 \mathrm{~m}^{3}\right)$ comprise about $80 \%$ of the river's highly variable average flow. An additional 5\% is owned by the heirs of early acequia farmers (now used for urban gardens) and the remaining $15 \%$ is unallocated, usually spilling from the reservoirs when the mountain snowpack melts in late spring. During the rest of the year, the river is a dry, heavily eroded ditch. This dewatering policy earned the Santa Fe River the designation of "America's Most Endangered River” (American Rivers 2007).

A new river management policy has been taking shape since 2008 , with surplus water being released from the dams more slowly in order to extend the period of river flow. A formal policy of releasing very small flows year-round is under consideration. Under this proposed "living river" policy, up to $1,233,481.84 \mathrm{~m}^{3}$ (1000 acre feet, i.e., equivalent to about $17 \%$ of the river's normal flow) would be released on a yearround basis, except in dry years, when the flow would be reduced proportionally.

\section{Reason about values}

The story of Santa Fe's relationship with its river is evolving. As Santa Fe's own colonial history demonstrates, values can and do change. Both the Pueblo culture that preceded Spanish colonialism, and the Hispanic agrarian-based culture that the United States annexed in 1848 still persist in the area, and the distinctiveness of those cultural traditions is one of the reasons that Santa Fe is a popular tourist destination today. Memories of river-fed irrigated farming as a way of life are part of the lore that grandparents tell their children (see Bello 2010). While the nineteenth century values that gave rise to the state's water laws are inimical to a flowing river, the contemporary value system is more diverse. Since the 1990s there have been several initiatives to bring the river back to life, including the formation of the Santa Fe Watershed Association (http://www. santafewatershed.org), and City investments dedicated to river and watershed restoration (see Borchert et al. 2010). The issue of "water in the river" has become a generalized goal for the community, but lacks any specific commitments to limit water use in favor of river flow (Groenfeldt 2008).

An important facilitating factor in the support for some flow in the river is the recently completed pipeline from the Rio Grande, which is $20 \mathrm{~km}$ away and which now supplements the City's surface (the Santa Fe River) and groundwater supplies. Allocating water to the river no longer comes at the expense of water for the people in Santa Fe City; indeed, the link between water conservation and water availability has effectively been removed. The Rio Grande pipeline enables the City to purchase new water rights on the Rio Grande and deliver the water to Santa Fe. The Santa Fe River remains the cheapest source of water, but it is not the only source. Whether to allocate water to river flow is now as much a financial decision as a moral or ethical one.

The Santa Fe case illustrates how place, scale, and values establish parameters for water governance in ways that fit all four of the governance approaches considered above. A management perspective identifies both physical and social developments, such as how acequias were supplanted by larger dams that presently impound most of the river's flow. An institutional perspective reveals how evolving laws and rights regimes inflect governance with different political and economic domains of power. Water laws based on prior appropriation and the concept of "beneficial use" give legal justification to the dewatering of the river for municipal water supply. A social-ecological perspective looks at the dynamics and the context of the community and the river. For instance, the recent construction of the Rio Grande pipeline was the realization of finding water "for the river" without altering community values. Clearly, however, this raises questions of the scale at which the socio-hydrological cycle is considered and how securing community values in one place, Santa Fe, comes at a cost to other types of social-ecological communities previously supported by the water now diverted from the Rio Grande.

The values approach connects water governance to both place and scale. It sees the history of acequia culture, colonial laws and infrastructure, and emerging social-ecological considerations as both responding to previous governance practices and as an introduction to a response to support certain policy aims over others. The water ethic revealed in the Santa Fe case shows how landscapes are co-designed places where an understanding of both history and scale are needed for developing an ecological realism (Delli Priscoli 2000, Folke 2003). A values approach does not support a conclusion that 
all of the values affecting water in the Santa $\mathrm{Fe}$ are commensurable; not all values can be "traded-off" against each other. For example, even though the prior appropriation doctrine emerged expressly to stop water rights from being treated as private property (Schorr 2005), the water rights are now increasingly re-interpreted as such through the utilitarian ethic that underlies economics (see also Wilkinson 1989). In this way, the Santa Fe case returns this discussion to the broader context of global governance and the challenge of ordering water without using categories that are particular to only a subset of the communities affected by changing governance regimes (Schmidt 2012).

\section{CONCLUSION: ORDERING WATER ANEW}

In this paper we discussed three approaches to water governance-management, institutions, and social-ecological -and then proposed a "values approach" to deepen our understanding of water governance. We suggest that these approaches overlap, and thus offer complementary insights. But the values approach is of special importance because it possesses explanatory power and has been largely overlooked in discussions of water governance. Focusing on the underlying values of water policies enables a clearer understanding of how different normative considerations regarding place and scale combine as part of a water ethic.

Pahl-Wostl et al. (2008) concluded a theoretical assessment of global water governance by asking what kind of normative governance framework is needed to link economic, environmental, and social water challenges. In this paper we suggest that values are more than a residual category to cover anything that water management, institutions, or socialecological science do not explain. Rather, a values approach identifies the reasoning used to support laws, policies, and practices; it seeks to describe and explain those values; and it considers how alternate categories for defining the humanwater relationship affect the ethic of governance. In so doing, a values approach connects place and scale to the justifications offered for pursuing certain policy paths over others. As such, it enables an explicit dialogue regarding both the reasons and values affecting water, ethics, and governance.

A values approach to water governance does not resolve ethical dilemmas, but it improves our understanding of how and why ethical issues are central to the task of adapting technical and political issues to changing patterns of water governance (Delli Priscoli 2004, Whiteley et al. 2008). The Santa Fe case illustrates the larger challenge faced in global governance of giving a fair hearing to the multiple and often conflicting values that affect water in social-ecological systems, particularly in the face of climate change (Groenfeldt 2010).

How can we move from acknowledging policy gaps to constructive debate? A first step is to recognize that a sufficient grasp of our values and the effects of legal and governance decisions are central to motivating responsive action (Flournoy 2003). A second step is to assess the appropriate governance channel for change. Not all governance adjustments must work through formal legal mechanisms, nor may they only be oriented towards mainstream economic values (see Soderbaum 2008). A third step is to recognize that water governance cannot avoid value judgments (Schmidt 2010) nor can it avoid engaging with how multiple spheres of value establish standards of equity (Pradhan and MeinzinDick 2003, Whiteley et al. 2008).

Does the solution to good water governance lie in management improvements, institutional reforms, or social-ecological analysis? In this paper we have suggested that each approach has much to contribute to water governance, but each approach could be enhanced through explicit attention to underlying values. Our suggestions go further: a values approach constitutes an important approach in its own right. In the Santa Fe case, a values-based approach helps identify where the central normative problems lie and suggests alternate values upon which to coordinate governance. At the global level, where coordinating norms affect multiple types of human and nonhuman communities, clear articulation of water ethics is essential for recognizing when and where values affect the aims and ends of water governance.

Responses to this article can be read online at: http://www.ecologyandsociety.org/issues/responses. $\mathrm{php/4629}$

\section{Acknowledgments:}

The authors thank the coordinating editors of this special feature on global water governance. Jeremy Schmidt acknowledges the funding provided by the Trudeau Foundation and the Social Sciences and Humanities Research Council of Canada (SSHRC).

\section{LITERATURE CITED}

Acreman, M. 2004. Water and ethics: water and ecology. UNESCO, Paris, France.

Acreman, M., M Dunbar, J. Hannaford, O. Mountford, P. Wood, N. Holmes, et al. 2008. Developing environmental standards for abstractions from UK rivers to implement the EU water framework directive. Hydrological Sciences 53:1105-1120. http://dx.doi.org/10.1623/hysj.53.6.1105

Agarwal, A., M. S. delos Angeles, R. Bhatia, I. Chéret, S. Davila-Poblete, M. Falkenmark, F. G. Villarreal, T. JønchClausen, M. A. Kadi, J. Kindler, J. Rees, P. Roberts, P. Rogers, 
M. Solanes, and A. Wright. 2000. Integrated water resources management. Technical Advisory Committee Background Paper 4. Global Water Partnership, Stockholm, Sweden.

Agrawal, A. 2003. Sustainable governance of common-pool resources: context, methods and politics. Annual Review of Anthropology 32:243-262. http://dx.doi.org/10.1146/annurev. anthro.32.061002.093112

American Rivers. 2007. America's most endangered rivers of 2007. American Rivers, Washington, D.C., USA.

Anderson, T., and D. Leal. 2001. Free market environmentalism: revised edition. Palgrave, New York, New York, USA.

Annear, T. C., I. Chisholm, H. Beecher, A. Locke, P. Aarrestad, N. Burkhart, et al. 2002. Instream flows for riverine resource stewardship. Instream Flow Council, Cheyenne, Wyoming, USA.

Arthington, A. H., S. E. Bunn, N. L. Poff, and R. Naiman. 2006. The challenge of providing environmental flow rules to sustain river ecosystems. Ecological Applications 16:1311-1318. http://dx.doi.org/10.1890/1051-0761(2006)016[1311:TCOPEF] 2.0.CO;2

Aureli, A., and C. Brelet. 2004. Women and water: an ethical issue. UNESCO, Paris, France.

Barraqu, B. 2004. Water and ethics: institutional issues. UNESCO, Paris, France.

Bauer, C. 2004. Results of Chilean water markets: empirical research since 1990. Water Resources Research 40:9. http:// dx.doi.org/10.1029/2003WR002838

Bello, K. 2010. The return of the river. Sunstone Press, Santa $\mathrm{Fe}$, New Mexico, USA.

Biswas, A., editor. 1978. United Nations water conference: summary and main documents. Pergamon Press, Oxford, Oxfordshire, UK.

Blatter, J., and H. Ingram, editors. 2001. Reflections on water: new approaches to transboundary conflict and cooperation. MIT Press, Cambridge, Massachusetts, USA.

Blomley, N. 2008. Simplification is complicated: property, nature, and the rivers of law. Environment and Planning A 40:1825-1842. http://dx.doi.org/10.1068/a40157

Boelens, R., M. Chiba, and D. Nakashima, editors. 2006. Water and indigenous peoples. Knowledges of Nature 2, UNESCO, Paris, France.

Boelens, R., D. Getches, and A. Guerva-Gill, editors. 2010. Out of the mainstream: water rights, politics and identity. Earthscan, London, UK.
Borchert, C., B. Drypolcher, and A. Lewis. 2010. Sustaining the Santa Fe River. Southwest Hydrology Jan/Feb:28-29

Brierley, G., and K. Fryiers. 2008. River futures: an integrative scientific approach to river repair. Island Press, Washington, D.C., USA.

Brown, F., and H. Ingram. 1987. Water and poverty in the southwest. University of Arizona Press, Tucson, Arizona, USA.

Brown, P. G., and J. J. Schmidt, editors. 2010. Water ethics: foundational readings for students and professionals. Island Press, Washington, D.C., USA.

Cech, T. 2004. Principles of water resources: history, development, management and policy. Second edition. Wiley, New York, New York, USA.

Chamberlain, G. 2008. Troubled waters: religion, ethics, and the global water crisis. Rowman and Littlefield Publishers, Lanham, Maryland, USA.

Chambers, R. 2007. From PRA to PLA and pluralism: practice and theory. Working Paper 286. Institute for Development Studies, University of Sussex, Brighton, East Sussex, UK.

Chambers, R., N.C. Saxena, and T. Shah. 1989. To the hands of the poor: water and trees. Oxford, New Delhi, India.

Conca, K. 2006. Governing water: contentious transnational politics and global institution building. MIT Press, Cambridge, Massachusetts, USA.

Coward, E. 1980. Irrigation and agricultural development in Asia: perspectives from the social sciences. Cornell University Press, Ithaca, New York, USA.

Dasgupta, P., and I. Serageldin. 2000. Social capital: a multifaceted perspective. World Bank, Washington, D.C., USA.

Delli Priscoli, J. 1996. The development of transnational regimes for water resources management. Pages 19-38 in $\mathrm{M}$. A. Abu-zeid and A.K. Biswas, editors. River basin planning and management. Oxford University Press, Calcutta, India.

Delli Priscoli, J. 2000. Water and civilization: using history to reframe water policy debates and to build a new ecological realism. Water Policy 1:623-636.

Delli Priscoli, J. 2004. What is public participation in water resources management and why is it important? Water International 29(2):221-227.

Delli Priscoli, J., Dooge, J., and Llamas, R. 2004. Water and ethics: overview. Series on Water and Ethics, Essay 1. UNESCO, Paris, France. 
Dinar, A., K. Kemper, W. Blomquist, and Kurukulasuriya, P. 2007. Whitewater: decentralization of river basin water resources management. Journal of Policy Modeling 29:851-867.

Durant, R.J., D.J. Fiorino, and R. O'Leary, editors. 2004. Environmental governance reconsidered: challenges, choices and opportunities. MIT Press, Cambridge, Massachusetts, USA.

Dyson, M., G. Bergkamp, and J. Scanlon, editors. 2003. Flow: the essentials of environmental flows. International Union for Conservation of Nature (IUCN), Gland, Switzerland. http:// dx.doi.org/10.2305/IUCN.CH.2003.WANI.2.en

Espelund, W. N. 1998. The struggle for water: politics, rationality, and identity in the American Southwest. University of Chicago Press, Chicago, Illinois, USA.

Falkenmark, M., and C. Folke. 2002. The ethics of socioecohydrological catchment management: toward hydrosolidarity. Hydrology and Earth System Sciences 6:1-10. http://dx.doi. org/10.5194/hess-6-1-2002

Falkenmark, M., and C. Folke. 2010. Ecohydrosolidarity: a new ethics for stewardship of value-adding rainfall. Pages 247-264 in P. G. Brown, and J. J. Schmidt, editors. Water ethics: foundational readings for students and professionals. Island Press, Washington, D.C., USA.

Falkenmark, M., and J. Rockström. 2004. Balancing water for humans and nature: the new approach in ecohydrology. Earthscan, London, UK.

Feldman, D. 1995. Water resources management: in search of an environmental ethic. John Hopkins University Press, Baltimore, Maryland, USA.

Feldman, D. 2007. Water policy for sustainable development. John Hopkins University Press, Baltimore, Maryland, USA.

Flournoy, A. 2003. Building an environmental ethic from the ground up. Environmental Law and Policy Journal 56:575-586.

Folke, C. 2003. Freshwater for resilience: a shift in thinking. Philosophical Transactions of the Royal Society of London B 358:2027-2036. http://dx.doi.org/10.1098/rstb.2003.1385

Freyfogle, E. 1996. Water rights and the common wealth. Environmental Law 26:27-51.

Gaard, G. 2001. Women, water, energy: an ecofeminist approach. Organization \& Environment 14:157-172. http://dx. doi.org/10.1177/1086026601142002

Garrido, A., and H. Ingram. 2011. Water for food in a changing world. Routledge, New York, New York, USA.
Gerber, L. 2003. The nature of water: Basia Irland reveals the 'is' and the 'ought'. Ethics \& the Environment 8:37-50. http:// dx.doi.org/10.2979/ETE.2003.8.1.37

Groenfeldt, D. 1988. The potential for farmer participation in irrigation system management. Irrigation and Drainage Systems 2(3):241-257. http://dx.doi.org/10.1007/BF01103624

Groenfeldt, D. 2008. My view: time to rescue Santa Fe's endangered river. Santa Fe New Mexican, April 20. [online] URL: http://www.santafenewmexican.com/Opinion/My-ViewTime-to-rescue-Santa-Fe-s-endangered-river.

Groenfeldt, D. 2010. The next nexus: environmental ethics, water management, and climate change. Water Alternatives 3 (3):575-586.

Gunderson, L., and C. S. Holling, editors. 2002. Panarchy: understanding transformations in human and natural systems. Island Press, Washington, D.C., USA.

Gupta, J., A. Akhmouch, W. Cosgrove, Z. Hurwitz, J. Maestu, and O. Ünver. 2013. Policymakers' reflections on water governance issues. Ecology and Society (in press).

Hanemann, W. M. 2006. The economic conception of water. Pages 61-91 in P. P. Rogers, M. R. Llamas, and L. MartinezCortina, editors. Water crisis: myth or reality? Taylor and Francis, London, UK. http://dx.doi.org/10.1201/9781439834275. pt2a

Huitema, D., E. Mostert, W. Egas, S. Moellenkamp, C. PahlWostl, and R. Yalcin. 2009. Adaptive water governance; assessing the institutional prescriptions of adaptive (co-) management from a governance perspective and defining a research agenda. Ecology and Society 14(1):26. [online] URL: http://www.ecologyandsociety.org/vol14/iss 1/art26/.

Hulme, M. 2010. Problems with making and governing global kinds of knowledge. Global Environmental Change 20:558-564.

Illich, I. 1986. $\mathrm{H}_{2} \mathrm{O}$ and the waters of forgetfulness. Marion Boyars Publishers, London, UK. http://dx.doi.org/10.2307/4611047

Irland, B. 2007. Water library. University of New Mexico Press, Albuquerque, New Mexico, USA.

Johnston, B. R. 1994. Who pays the price? The sociocultural context of environmental crisis. Island Press, Washington, D. C., USA.

King, J., and C. Brown. 2006. Environmental flows: striking the balance between development and resource protection. Ecology and Society 11(2):26. [online] URL: http://www. ecologyandsociety.org/vol11/iss2/art26/. 
Korten, F., and R. Siy. 1988. Transforming a bureaucracy: the experience of Philippine national irrigation administration. Kumarian Press, West Hartford, Conneticut, USA.

Kysar, D. 2010. Regulating from nowhere: environmental law and the search for objectivity. Yale University Press, New Haven, Conneticut, USA.

Lindblom, C. 1999. A century of planning. Pages 39-65 in K. Meadowcroft, editor. Planning sustainability. Routledge, New York, New York, USA.

Llamas, R. 2004. Water and ethics: use of groundwater. UNESCO, Paris, France.

Llamas, R., L. Martinez-Cortina, and A. Mukherji, editors. 2009. Water ethics: Marcelino Botin water forum 2007. CRC Press, London, UK.

Lövbrand, E., J. Stripple, B. Wiman. 2009. Earth system governmentality: reflections on science in the Anthropocence. Global Environmental Change 19:7-13. http://dx.doi. org/10.1016/j.gloenvcha.2008.10.002

Malano, H., and M. Burton. 2001. Guidelines for benchmarking performance in the irrigation and drainage sector. International Programme for Technology and Research in Irrigation and Drainage. FAO, Rome, Italy.

Merchant, C. 1997. Fish first! The changing ethics of ecosystem management. Human Ecology Review 4:25-30.

Merrey, D., and S. Basiskar, editors. 1998. Gender analysis and reform of irrigation management: concepts, cases and gaps in knowledge. Proceedings of the workshop on gender and water, September 1997. International Water Management Institute, Colombo, Sri Lanka.

Molle, F. 2009. River-basin planning and management: the social life of a concept. Geoforum 40:484-494.

Northwest Territories. 2010. Northern voices, northern waters: NWTwater stewardship strategy. [online] URL: http:// www.enr.gov.nt.ca/ live/documents/content/NWT Water Stewardship_Strategy.pdf.

Ostrom, E. 1990. Governing the commons: the evolution of institutions for collective action. Cambridge University Press, New York, New York, USA.

Ostrom, E. 1992. Crafting institutions for self-governing irrigation systems. ICS Press, San Francisco, California, USA.

Ostrom, E. 2005. Understanding institutional diversity. Princeton University Press, Princeton, New Jersey, USA.

Ostrom, E. 2009. A general framework for analyzing sustainability of socio-ecological systems. Science 325:419-422. http://dx.doi.org/10.1126/science.1172133
Ostrom, E. 2010. Polycentric systems for coping with collective action and global environmental change. Global Environmental Change 20(4):550-557.

Pahl-Wostl, C., J. Gupta, and D. Petry. 2008. Governance and the global water system: a theoretical exploration. Global Governance 14:419-435.

Pant. N., editor. 1984. Productivity and equity in irrigation systems. Ashish Publishing House, New Delhi, India.

Parfit, D. 2011. On what matters: volume one. Oxford University Press, New York, New York, USA.

Phansalkar, S. J., and S. Verma. 2004. Improved water control as strategy for enhancing tribal livelihoods. Economic and Political Weekly July 31:3469-3476.

Pigram, J. 2006. Australia's water resources: from use to management. CSIRO Publishing, Collingwood, Victoria, Australia.

Postel, S. 2008. The missing piece: a water ethic. The American Prospect 19(6). [online] URL: http://www.prospect.org/cs/ articles?article=the $\_$missing_piece_a water_ethic.

Postel, S., and B. Richter. 2003. Rivers for life: managing water for people and nature. Island Press, Washington, D.C., USA.

Pradhan, R., and R. Meinzen-Dick. 2003. Which rights are right? Water rights, culture, and underlying values. Water Nepal 9(19):37-61. http://dx.doi.org/10.3126/wn.v10i1.93

Rahaman, M. M., and O. Varis. 2005. Integrated water resources management: evolution, prospects and future challenges. Sustainability: Science, Practice \& Policy 1:25-21.

Robertson, M. 2007. Discovering price in all the wrong places: the work of commodity definition and price under neoliberal environmental policy. Antipode 39:500-526. http://dx.doi. org/10.1111/j.1467-8330.2007.00537.x

Rodriguez, S. 2006. Acequia: water-sharing, sanctity and place. School for Advanced Research Press, Santa Fe, New Mexico, USA.

Rolston, H. 2010. Value in nature and the nature of value. Pages 130-137 in D. Keller, editor. Environmental ethics: the big questions. Wiley-Blackwell, Malden, Massachusetts, USA. http://dx.doi.org/10.1017/CBO9780511524097.004

Sandberg, A. 2007. Property rights and ecosystem properties. Land Use Policy 24:613-623.

Sandford, R. and M-A. Phare. 2011. Ethical water: learning to value what matters most. Rocky Mountain Books, Surrey, British Columbia, Canada. 
Schmidt, J. 2010. Water ethics and water management. Pages 3-15 in P. G. Brown and J. J. Schmidt, editors. Water ethics: foundational readings for students and professionals. Island Press, Washington, D.C., USA. http://dx.doi.org/10.2307/1964271

Schmidt, J. 2012. Scarce or insecure? The right to water and the changing ethics of global water governance. Pages 94-109 in F. Sultana and A. Loftus, editors. The right to water: politics, governance and social struggles. Routledge, London, UK.

Schorr, D. 2005. Appropriation as agrarianism: distributive justice in the creation of property rights. Ecology Law Quarterly 32:3-71.

Selborne [Lord] . 2000. The ethics of freshwater use: a survey. UNESCO, Paris, France.

Shaw, S., and A. Francis, A. 2008. Deep blue: critical reflections on nature, religion and water. Equinox, London, UK.

Soderbaum, P. 2008. From mainstream 'environmental economics' to 'sustainability economics'. On the need for new thinking. Journal of Environmental Monitoring 10:1467-1475. http://dx.doi.org/10.1039/b811379n

Sultana, F. 2011. Suffering for water, suffering from water: emotional geographies of resource access, control and conflict. Geoforum 42:163-172.

Swyngedouw, E. 2005. Dispossessing $\mathrm{H}_{2} \mathrm{O}$ : the contested terrain of water privatization. Capitalism, Nature, Socialism 16:1-18. http://dx.doi.org/10.1080/1045575052000335384

Tarlock, D. 1993. The nonequilibrium paradigm in ecology and the partial unraveling of environmental law. Loyala of Los Angelas Law Review 27:1121-1141.

Vaux, H. 2010. Equity in policy: failure and opportunity. Natural Resources Journal 50:517-538.

Warner, J., P. Wester, and A. Boldin. 2008. Going with the flow: river basins as the natural units for water management? Water Policy 10:121-138.

White, G. 1998. Reflections on the 50-year international search for integrated water management. Water Policy 1:21-27.

White, G. F. 1969. Strategies of American water management. University of Michigan Press, Ann Arbor, Michigan, USA.

Whiteley, J., H. Ingram, and R. Perry, editors. 2008. Water, place, and equity. MIT Press, Cambridge, Massachusetts, USA.
Wickham, T., editor. 1985. Irrigation management: research from southeast Asia. Agricultural Development Council, New York, New York, USA.

Wiener, A. 1972. The role of water in development: an analysis of principles of comprehensive planning. McGraw-Hill Book Company, New York, New York, USA.

Wilkinson, C. 1989. Aldo Leopold and western water law: thinking perpendicular to the prior appropriation doctrine. Land and Water Law Review 24:1-38.

Wolf, A. T. 2008. Healing the Enlightenment rift: rationality, spirituality and shared waters. Journal of International Affairs 61:51-73.

Zwarteveen, M., and R. Meinzin-Dick. 2001. Gender and property rights in the commons: examples of water rights in South Asia. Agriculture and Human Values 18:11-25. http:// dx.doi.org/10.1023/A:1007677317899 